\title{
Impact of Transformational Leadership on \\ Organizational Innovation: Telecommunication Sector of Pakistan
}

\author{
Muhammad Yousaf Malik (Corresponding author) \\ Institute of Business Management Sciences, University of Agriculture Faisalabad \\ Zip Code 38000, University Road, Faisalabad, Pakistan \\ Tel: 92-41-9201096Ｅ-mail: yousaf.malik@uaf.edu.pk
}

Aon Waqas Awan

School of Business, Shaheed Benazir Bhutto University Shaheed Benazirabad

Zip Code 67450, Shaheed Benazirabad, Sindh, Pakistan

Tel: 92-244-937-0527Ｅ-mail: aonwaqas@ sbbusba.edu.pk

Received: October 10, 2016 Accepted: November 17, 2016

doi:10.5296/ber.v6i2.10140ＵRL: http://dx.doi.org/10.5296/ber.v6i2.10140

\begin{abstract}
This study aims at finding out how transformational leadership effects the organizational innovation in leading telecommunication companies of Pakistan. The study used a well-established questionnaire for data collection. The data was collected through convenient sampling from 120 mid-level and high-level managers of telecommunication organizations. The study not only relied on emphasis of descriptive statistics but regression was run to analyze the data. The results exhibit that transformational leadership has a constructive and substantial impact on organizational innovation in the deliberated context. This study is deemed to guide the Pakistan's Telecommunication sector to improve the way management can yield more value from their employees. It also shows the impact of globally recognized knowledge can work in varying cultures and contexts.
\end{abstract}

Keywords: Transformational leadership, Organizational innovation, Pakistan telecommunication sector 


\section{Introduction}

Organizations today are operating in a very dynamic environment, which include rapidly changing technology and Globalization. This requires organizations to bring innovation to their product and services and keep investing on R \& D. The organizations, especially that are technology-driven must be innovative and creative to compete and survive (Gumusluoglu and Ilsev, 2009). Innovation by creativity is critical for the organizations to uphold a comparative and competitive advantage. This is why utmost importance is being given to the creativity as well as innovation by every leading organization (Mumford and Gustafson, 2002). Innovation is considered to be at organizational level and creativity is at the level of an individual. Organizations and their creation process are central to the course they choose for innovation (Van de Ven et al, 2005). Generally, organization innovation is associated with adoption of a certain idea or behavior that is very unique and new to the organization (Daft, 1978; Evan, 1984 and Damanpour, 1996). Leadership exists among those important aspects that affect organizational innovation (Oldham and Cumming, 1996).

Changing environment and rapid business environment have made leadership even more important than before. Existing organizations are focusing on strategies to revitalize and transform themselves to cater for the competitive challenges that have instigated interest in researchers regarding studies related to Transformational Leadership. Transformational Leadership is very useful and appropriate for identification of new opportunities and also for development of appropriate competences in the organizations. Northhouse (2001) has suggested that the Transformational Leadership help achieve higher performance outcomes and also exceeds expectations from an organization.

To our knowledge, there exists no such research in which the transformational leadership is studied directly in relation to organizational innovation, there is always any other third variable or internal or external effect included.

Our aim is find out the relationship between transformational leadership and organizational innovation without considering any other factor or effect of any external or internal support. There has been no work done in this specific context in Pakistan. Thus, only transformational leadership and its impact on organizational innovation in the telecommunication sector is observed as it's the most rapidly growing sector in Pakistan.

\section{Literature Review}

Transformational leaders are expected and have been suggested to have a definite effect on innovation. They exalt innovation in the context of the organizations. According to Elkins and Keller (2003), transformational leaders use their inspirational powers such as inspirational motivation and their intellect such as intellectual stimulation to engage organization members in innovation activities.

Such leaders encourage creativity in their organizations. Transformational leaders behave in such manner as "creativity-enhancing forces"; individualized consideration "serves as a reward" for the followers, intellectual stimulation "enhances exploratory thinking", and inspirational motivation "provides encouragement into the idea generation process" (Sosik, 
Kahai and Avolio, 1998). Transformational leaders show a behavior that reflects them being the champions of the organization (Howell and Higgins, 1990). They are expected to develop and promote the needs of confidence, efficacy and esteems in their followers (Bass, 1990). Transformational leaders motivate their followers by articulating the vision and increases their willingness to perform the mentioned standards and encourages them for creativity.

The boost given to followers for their self-esteem needs is likely to increase the innovation of the organization (Mumford et al., 2002). Moreover, there is a handsome number of empirical researches that show an impact of Transformational leadership having a positive impact on organizational innovation (e.g., Keller, 1992; Waldman and Atwater, 1994). R\&D units were the main focus among these studies and they related to organizational innovation. Recently, the organizational innovation has become a topic of research for the researchers and they want to see its relationship with transformational leadership. Jung et al, (2003) studied the above-mentioned relationship and measured it by $R \& D$ expense and the no. of patents acquired for a certain period of three years. This study extended the literature on the subject in two essential facets. Firstly, they proposed an integrated model that associated transformational leadership with organizational innovation directly as well as by mediation of forces relating to organization and its environment. Secondly, it gave a multi-dimensional measurement of innovation in the organization that was inclusive of many variables that were not considered before. There is use of R\&D expense as a percentage of revenues (gross), which can be aptly utilized as an indicator for innovation (Balkin et al, 2000). In their study, they collected data from employees of 53 firms in Taiwan. Multifactor Leadership Questionnaire (MLQ) was utilized to get measurement regarding Transformational Leadership. Perception of employees regarding them being empowered was measured using a 12- item scale that was developed by Spreitzer (1995). Organizational climate that supports innovation was measured by 22-item scale made by Siegel and Kaemmerer (1978). Data analysis shows that transformational leadership enhances the organizational innovation.

Likewise, the study of Lale et al. (2003) determined the contextual conditions for innovation (internal support + external support) having an influence on how transformational leadership impacts organizational innovation. Transformational leadership was found to have a positive relationship with organizational innovation. This impact was suggested to be restrained by internal support for innovation, internal support is considered as innovation supportive climate and suitable resources allotted to innovation. Support gained from external organizations for the purposes of information collection and resource procurement was considered as moderating variable between transformational leadership and organizational innovation as well.

Questionnaires used to collect the data were two separate ones, one was for employees and the second one was for managers. Hierarchical regression was utilized to analyze the hypothesized impacts. Findings showed a positive relationship between both variables. This was also inferred that if the external support is present, the relationship between transformational leadership and organizational innovation becomes stronger. In the absence of such external support the relationship is weaker. 
García-Morales et al. (2012) revealed that 1) there is a positive influence of Transformational leadership on organizational performance provided organizational learning and innovation is observed. 2) Organizational learning positively impacts the performance of the organization directly and indirectly through organizational innovation. 3) Organizational innovation impacts positively on the performance of organization. Same results about organizational innovation and transformational leadership were depicted by a study done by Nourzy et al. (2013). In the context of Pakistan, the study of Khan et al. (2009) come up with the results that there is a significant moderating impact of organizational size, when a relationship between the aspects of Transformational Leadership and organizational innovation is deliberated. They noticed that except idealized influence all the other factors such as Attributed Charisma, intellectual stimulation, individualized consideration and intellectual stimulation had an impact on the above-mentioned relationship.

They exhibited positive and significant influence of transformational leadership on organizational innovation. In the light of previous literature, it is obvious that there is very strong association between transformational leadership and organizational innovation. In all the previous studies the effect of transformational leadership on organizational innovation was not measured directly, there are always some other variables involved. But as findings from all the previous researches suggest that there is a relation between them, so, we would like to measure the effect of transformational leadership on organizational innovation directly, without any other variable involved. We will purely study their relation in telecommunication industry of Pakistan, as none of the researcher in Pakistan has explored this area, so, there is immense need of research in this area.

\section{Methodology}

The determination for the study was to observe the effect of transformational leadership on the organizational innovation. Convenient sampling was used in the study. High and mid-level managers of top 6 telecommunication companies in Pakistan (Mobilink, Ufone, PTCL, Zong, Warid, and Telenor) were taken as sample for this study. Questionnaires were distributed among the managers of all the five companies. More than 130 questionnaires were distributed out of which we selected 120 questionnaires that were appropriate to be analyzed. Different tests were applied on the collected data to justify the proposed hypothesis.

\section{Results \& Discussions}

The descriptive statistics show the mean and standard deviation (SD) of the considered variables. The value of mean for transformational leadership calculated is 77.63 and for Organizational Innovation we have 48.57 in table 1 . The value of standard deviation is 10.10 and 6.01 for transformational leadership and organizational innovation respectively.

Table 1. Descriptive Statistics (N=120)

\begin{tabular}{|l|l|l|l|l|}
\hline Variables & Minimum & Maximum & Mean & Std. Deviation \\
\hline TL & 41 & 98 & 77.63 & 10.10 \\
\hline OI & 35 & 60 & 48.57 & 6.01 \\
\hline
\end{tabular}


Reliability test have been applied on 120 questionnaires comprising of 25 questions among which 17 were related to transformational leadership and 8 were in related to organizational innovation, as shown in table 2. We got the value of alpha after the application of test for both Transformational leadership and organizational innovation which is .85 and .66 respectively. Alpha shows the reliability of the instrument. The reliability value more than 0.60 shows that questionnaires items are reliable for data collection.

Table 2. Alpha Coefficient of Transformational Leadership and Organizational Innovation $(\mathrm{N}=120)$

\begin{tabular}{|c|c|c|}
\hline Variable Name & No. of Items & Alpha \\
\hline Transformational Leadership & 17 & .85 \\
\hline Organizational Innovation & 9 & .66 \\
\hline
\end{tabular}

Finally, the study used regression analysis. This study's results show that the $\beta=.257$ which presents the affirmative, robust and important relationship between the two variables "Transformational Leadership and Organizational Innovation". R2 is showing 6.6\%, which means that independent variable "Transformational Leadership" was able to explain $6.6 \%$ variations of dependent variable "Organizational Innovation. F-test statistics is used to analyze fitness of the model, null hypothesis of f-test states that "Model is not fit". Our study successfully reject null hypothesis, as tabulated value of f-test is less than our calculated value $(\mathrm{F}=4.10, \mathrm{P}<.047)$, which significantly prove that our "Model is fit".

Table 3. Regression Analysis ( $\mathrm{N}=120)$

\begin{tabular}{|l|llcc|}
\hline Model & B & Standard error & $\boldsymbol{\beta}$ & t \\
\hline Constant & 36.68 & 5.91 & -- & 6.207 \\
Transformational Leadership & 0.153 & 0.076 & 0.257 & 2.026 \\
$\mathrm{R}^{2}=0.066$ & & & & \\
$(\mathrm{~F}=4.10, \mathrm{P}<0.047)$ & & & & \\
\hline
\end{tabular}

Discussion: Organizations are now facing a vibrant environment with high value of innovation and global competition. Leadership has a great impact on the organization and bringing innovation to it. There is an increasing importance of leadership especially transformational leadership over the past three decades in the organizational success through innovation.

For a sustained innovation culture the transformational leaders and companies have to incorporate innovation and creativity in their strategy.

The Study serves as reference for relationship status of transformational leadership on organizational innovation in context of Pakistan within the boundaries of telecommunication industry. Hypothesis developed proposed a positive impact of transformational leadership on organizational innovation. The Beta value $(\beta=.257)$ shows positive and significant relationship between transformational leadership and organizational innovation. The value of R-Square showed $6 \%$ variance $(\mathrm{F}=4.106, \mathrm{P}<.05)$ grounded by transformational leadership and organizational innovation. The study results are in line with the researches done 
previously like researches that focus on the topic that are "Towards understanding direct and indirect effect of transformational leadership on firm innovation" (Jung Chow and Anne Wu , 2003), the result revealed that transformational leadership increases and have a positive effect on organizational innovation, as in study of Ilsev et al. (2009) titled "Transformational leadership and organizational innovation: role of internal and external support". This study also clarifies the relationship between organizational innovation and transformational leadership that the latter is a critical factor and has a significant influence on the former variable. Transformational leadership behavior should be incorporated to get the most in terms of organizational innovation as also indicated in the study of J. Garcia et al. (2008) titled "Influence of transformational leadership on organizational innovation and performance depending on the level of organizational learning in the pharmaceutical sector".

It also viewed transformational leadership having an important influence on organizational innovation. There has been quite much work done on this relationship but there is still room for exploring more especially in Pakistan.

\section{Conclusion}

It is concluded that transformational leadership play a vital part in the organizational innovation. Leaders using transformational leadership style will try and provide greater opportunities for innovation as compared to the leaders using leadership style other than transformational leadership. The results of this study showed that there is a positive relationship between Transformational Leadership and Organizational Innovation. The organizations should encourage the Transformational Leadership style, to bring change and innovative ideas. By doing so they will be able to offer exclusive products to the market, this will boost their market share. Every leader/manager should adopt transformational style of leadership, so that they and their subordinates can raise themselves to better and higher tier of motivation and morality.

\section{References}

Bass, B. M. (1991). From transactional to transformational leadership: Learning to share the vision. Organizational dynamics, 18(3), 19-31. doi:10.1016/0090-2616(90)90061-S

Bass, B. M., \& Avolio, B. J. (1997). Full range leadership development: Manual for the Multifactor Leadership Questionnaire (pp. 43-44). Palo Alto, CA: Mind Garden.

Daft, R. L. (1978). A dual-core model of organizational innovation. Academy of management journal, 21(2), 193-210. http://dx.doi.org/10.2307/255754

Damanpour, F. (1991). Organizational innovation: A meta-analysis of effects of determinants and moderators. Academy of management journal, 34(3), 555-590.

http://dx.doi.org/10.2307/256406

Damanpour, F., \& Evan, W. M. (1984). Organizational innovation and performance: the problem of "organizational lag". Administrative science quarterly, 392-409.

http://dx.doi.org/10.2307/2393031 
Elkins, T., \& Keller, R. T. (2003). Leadership in research and development organizations: A literature review and conceptual framework. The Leadership Quarterly, 14(4), 587-606. http://dx.doi.org/10.1016/S1048-9843(03)00053-5

García-Morales, V. J., Jiménez-Barrionuevo, M. M., \& Gutiérrez-Gutiérrez, L. (2012). Transformational leadership influence on organizational performance through organizational learning and innovation. Journal of Business Research, 65(7), 1040-1050. http://dx.doi.org/10.1016/j.jbusres.2011.03.005

Howell, J. M., \& Higgins, C. A. (1990). Champions of technological innovation. Administrative science quarterly, 317-341. http://dx.doi.org/10.2307/2393393

Jung, D. I. (2001). Transformational and transactional leadership and their effects on creativity in groups. Creativity Research Journal, 13(2), 185-195.

http://dx.doi.org/10.1207/S15326934CRJ1302_6

Jung, D. I., Chow, C., \& Wu, A. (2003). The role of transformational leadership in enhancing organizational innovation: Hypotheses and some preliminary findings. The Leadership Quarterly, 14(4), 525-544. http://dx.doi.org/10.1016/S1048-9843(03)00050-X

Keller, R. T. (1992). Transformational leadership and the performance of research and development project groups. Journal of management, 18(3), 489-501.

http://dx.doi.org/10.1177/014920639201800304

Khan, R., Rehman, A. U., \& Fatima, A. (2009). Transformational leadership and organizational innovation: Moderated by organizational size. African Journal of Business Management, 3(11), 678. http://dx.doi.org/10.5897/AJBM09.203

Gumusluoglu, L., \& Ilsev, A. (2009). Transformational leadership, creativity, and organizational innovation. Journal of business research, 62(4), 461-473. http://dx.doi.org/10.1016/j.jbusres.2007.07.032

Gumusluoğlu, L., \& Ilsev, A. (2009). Transformational leadership and organizational innovation: The roles of internal and external support for innovation. Journal of Product Innovation Management, 26(3), 264-277. http://dx.doi.org/10.1111/j.1540-5885.2009.00657.x

Mumford, M. D., Scott, G. M., Gaddis, B., \& Strange, J. M. (2002). Leading creative people: Orchestrating expertise and relationships. The leadership quarterly, 13(6), 705-750. http://dx.doi.org/10.1016/S1048-9843(02)00158-3

Northhouse, P. G. (2001). Leadership. Theory and practice (2).

Noruzy, A., Dalfard, V. M., Azhdari, B., Nazari-Shirkouhi, S., \& Rezazadeh, A. (2013). Relations between transformational leadership, organizational learning, knowledge management, organizational innovation, and organizational performance: an empirical investigation of manufacturing firms. The International Journal of Advanced Manufacturing Technology, 64(5-8), 1073-1085. http://dx.doi.org/10.1007/s00170-012-4038-y

Oldham, G. R., \& Cummings, A. (1996). Employee creativity: Personal and contextual 
factors at work. Academy of management journal, 39(3), 607-634.

http://dx.doi.org/10.2307/256657

Siegel, S. M., \& Kaemmerer, W. F. (1978). Measuring the perceived support for innovation in organizations. Journal of Applied Psychology, 63(5), 553.

http://dx.doi.org/10.1037/0021-9010.63.5.553

Sinha, K. K., \& Van de Ven, A. H. (2005). Designing work within and between organizations. Organization Science, 16(4), 389-408. http://dx.doi.org/10.1287/orsc.1050.0130

Sosik, J. J., Kahai, S. S., and Avolio, B. J. (1998). Transformational Leadership and Dimensions of Creativity: Motivating Idea Generation in Computer-Mediated Groups. Creativity Research Journal, 11(2), 111-121. http://dx.doi.org/10.1207/s15326934crj1102_3

Spreitzer, G. 1995. Psychological empowerment in the workplace: Dimension, measurement, and validation. Academy of Management Journal, 38, 1442-1465.

http://dx.doi.org/10.2307/256865

Waldman, D. A. and Atwater, L.E. (1994). The Nature of Effective Leadership and Championing Processes at Different Levels in an R\&D Hierarchy. The Journal of High Technology Management Research, 5(2), 233-245.

http://dx.doi.org/10.1016/1047-8310(94)90004-3

\section{Copyright Disclaimer}

Copyright for this article is retained by the author(s), with first publication rights granted to the journal.

This is an open-access article distributed under the terms and conditions of the Creative Commons Attribution license (http://creativecommons.org/licenses/by/3.0/). 